\title{
PARTISIPASI PEMILIH PEREMPUAN PADA PEMILIHAN UMUM LEGISLATIF TAHUN 2019 DI KECAMATAN KOTO TANGAH KOTA PADANG
}

\author{
Fiska Darmawan Putri ${ }^{1}$, Indah Adi Putri ${ }^{2}$ \\ ${ }^{1}$ Jurusan Ilmu Politik, Fisip, Universitas Andalas, fiskadarmawan01@gmail.com \\ ${ }^{2}$ Jurusan Ilmu Politik, Fisip, Universitas Andalas
}

\begin{abstract}
Abstrak
Partisipasi politik adalah kegiatan seseorang atau kelompok orang untuk ikut serta secara aktif dalam kehidupan politik, yakni dengan cara memilih wakil-wakil rakyat dan secara langsung atau tidak secara langsung, mempengaruhi kebijakan pemerintah. Partisipasi politik telah menempatkan kesejajaran antara laki-laki dan perempuan dalam berpartisipasi politik. Partisipasi politik perempuan dalam pemilihan umum bisa dilakukan sebagai pemilih. Sebagai seorang pemilih, perempuan tentu memiliki berbagai faktor yang mempengaruhinya dalam berpartisipasi. Rumusan masalah dari penelitian ini yakni faktor apa yang mempengaruhi partisipasi pemilih perempuan pada pemilu legislatif tahun 2019 di Kecamatan Kota Tangah Kota Padang. Tujuan dari penelitian ini yaitu untuk mengidentifikasi faktor apa yang mempengaruhi partisipasi pemilih perempuan pada pemilu legislatif tahun 2019 di Kecamatan Kota Tangah Kota Padang. Adapun metode dari penelitian ini adalah metode kualitatif jenis studi kasus instrinsik dengan mengggunakan konsep partisipasi politik Ramlan Surbakti. Hasil penelitian ini menemukan bahwa faktor yang mempengaruhi partisipasi pemilih perempuan pada pemilu legislatif tahun 2019 di Kecamatan Kota Tangah Kota Padang adalah faktor kesadaran politik, kepercayaan kepada pemerintah, status sosial dan status ekonomi, dukungan orang tua dan suami. Serta terdapat bentuk-bentuk partisipasi politik pemilih perempuan di Kecamatan Koto Tangah pada pemilu legislatif tahun 2019 yaitu dengan pemberian suara, ikut menjadi panitia penyelenggara pemilu dan berbicara masalah politik.
\end{abstract}

Kata Kunci : partisipasi politik ; pemilih perempuan ; Kecamatan Koto Tangah.

\begin{abstract}
Political participation is the activity of a person or group of people to participate actively in political life, namely by electing representatives of the people and directly or indirectly influencing government policies. Political participation has placed equality between men and women in participating in politics. Women's political participation in general elections can be done as voters. As a voter, women certainly have various factors that influence their participation. The formulation of the problem from this research is what factors affect the participation of women voters in the 2019 legislative elections in Kota Tangah District, Padang City. The purpose of this study is to identify what factors influence the participation of women voters in the 2019 legislative elections in Kota Tangah District, Padang City. The method of this research is a qualitative method of intrinsic case study using the concept of political participation by Ramlan Surbakti. The results of this study found that the factors that influenced the participation of women voters in the 2019 legislative elections in Kota Tangah District, Padang City were political awareness factors, trust in the government, social and economic status, support from parents and husbands. And there are forms of political participation of women voters in Koto Tangah district in the 2019 legislative elections, namely by voting, joining the election organizing committee and talking about political issues.
\end{abstract}

Keywords: political participation ; female voters ; Koto Tangah District. 


\section{PENDAHULUAN}

Pemilu merupakan sarana perwujudan kedaulatan rakyat untuk menghasilkan pemerintah yang demokratis. Di sebuah negara demokrasi seperti Indonesia, pemilu menjadi sebuah agenda yang penting untuk dilaksanakan. Hal ini karena pemilu merupakan sebuah prasyarat bagi negara yang berpaham demokrasi, dan demokrasi sendiri merupakan sebuah sistem yang menjunjung tinggi suara rakyat. ${ }^{1}$ Senada dengan hal tersebut, Robert Dahl menyatakan bahwasannya sebuah negara yang menganut sistem demokrasi harus memiliki sebuah perwujudan seperti partisipasi dan kontestasi yang mewujud pada dibukanya kran sistem multipartai dan pemilu yang bebas dan adil. ${ }^{2}$ Salah satu prasyarat utama untuk mewujudkan pemilu yang demokratis adalah adanya partisipasi politik.

Undang-Undang Pemilu No. 7 tahun 2017 memberikan kesempatan kepada semua warga negara yang telah memenuhi persyaratan untuk turut berpartisipasi politik. Partisipasi politik merupakan kegiatan seseorang atau sekelompok orang untuk ikut serta secara aktif dalam kehidupan politik, dengan jalan memilih pimpinan negara, dan secara langsung atau tidak langsung mempengaruhi kebijakan pemerintah (public policy). ${ }^{3}$ Partisipasi politik telah menempatkan kesejajaran antara laki-laki dan perempuan dalam menentukan pilihan politiknya. Pemilu sebagai perwujudan demokrasi merupakan proses politik yang melibatkan seluruh warga negara baik itu laki-laki maupun perempuan.

Dalam perkembangannya, tingkat partisipasi politik warga negara, khususnya dalam pemilu tidak selalu menunjukkan tingkatan yang sama. Dalam kaitan ini, ada berbagai faktor yang mempengaruhi seseorang untuk berpartisipasi dalam kehidupan politik termasuk partisipasi politik dalam kegiatan pemilu. Menurut Ramlan Surbakti, faktor-faktor yang mempengaruhi partisipasi politik antara lain: kesadaran politik, kepercayaan terhadap pemerintah, status sosial dan status ekonomi, afiliasi politik orang tua, dan situasi. ${ }^{4}$

Partisipasi politik perempuan dalam pemilu bisa dilakukan sebagai pemilih. Pemilih perempuan merupakan kelompok yang sangat potensial dalam menentukan nasib bangsa ini. Karena jumlahnya yang banyak dan juga perempuan memiliki perbedaan baik dalam visi dan konsep tentang politik yang berasal dari kodratnya sebagai perempuan maupun perannya sebagai ibu. Oleh karena itu di asumsikan bahwa perempuan akan membawa fokus dan nilainilai perempuan ke dalam politik. Dan juga perempuan diharapkan bisa memilih calon pemimpin secara cerdas dan selektif.

Tahun 2019 merupakan pesta demokrasi. Dimana pemilu diadakan pada tanggal 17 April 2019. Indonesia serentak melaksanakan pesta demokrasi berupa Pemilihan Presiden (Pilpres) dan juga Pemilihan Legislatif (Pileg). Namun disini peneliti akan memfokuskan

\footnotetext{
${ }^{1}$ Miriam Budiardjo. 2008. Dasar-Dasar Ilmu Politik. Jakarta: Gramedia. Hal 461.

${ }^{2}$ Wahyu Widodo. 2018. Pelaksanaan Pemilu Serentak Tahun 2019 Ditinjau Dari Perspektif Politik Dan Hukum. Jurnal Meta-Yuridis. Vol 1. No 1. Hal 24.

${ }^{3}$ Miriam Budiardjo. 2008. Dasar-Dasar Ilmu Politik. Jakarta: Gramedia Pustaka Utama. Hal 367.

${ }^{4}$ Rani Safitri, S.Sos \& Dr. Oksep Adhayanto., MH. 2017. Partisipasi Politik Perempuan Dalam Menyukseskan Pemilu Legislatif Tahun 2014 Di Kelurahan Sungai Lekop Kabupaten Bintan. Jurnal Ilmu Pemerintahan. Vol. 2. No. 1. Hal 101.
} 
untuk meneliti Pemilihan Legislatif (Pileg)

Sumatera Barat merupakan salah satu di antara daerah yang ikut serta pada Pileg tahun 2019. Jumlah partisipasi pemilih terbanyak di Sumatera Barat terdapat di Kota Padang. Kota Padang sendiri memiliki 11 Kecamatan dan di antara 11 Kecamatan tersebut, Kecamatan Koto Tangah merupakan Kecamatan paling banyak pemilih. Pemilih perempuan terbanyak juga terdapat di Kecamatan Koto Tangah. Hal ini menunjukkan bahwa perempuan juga antusias dalam berpartisipasi dan mendukung pelaksanaan Pileg tahun 2019. Partisipasi yang dilakukan oleh perempuan sangat menentukan hasil dari Pileg, selain dari itu partisipasi politik perempuan juga merupakan sebuah pembelajaran yang sangat berarti dimasa yang akan datang.

Berdasarkan tinjauan peneliti terdahulu mengenai partisipasi perempuan dalam politik itu menunjukkan hasil yang beragam. Penelitian Ana Maria Gadi Djou, MA dan Liza Quintarti (2018) dengan judul penelitian "partisipasi perempuan dalam partai politik dan pemilu serempak" yang mengatakan bahwasannya dalam meningkatkan keterwakilan perempuan didalam parlemen sejatinya tidak hanya berbicara agar perempuan mampu mengakomodir kepentingan semata, tetapi juga terdapat nilai-nilai yang lebih dalam, yaitu etika kepedulian yang menggambarkan cara khas perempuan dalam bereksistensi. ${ }^{5}$

Penelitian lain serupa juga dilakukan oleh Eko Ari Wibowo, Muradi, dan Arif Sudirman (2019) dengan judul "strategi sosialisasi dalam peningkatan partisipasi pemilih perempuan pada Pilkada serentak di kota Magelang" yang mengatakan bahwasannya pendekatan yang paling efektif digunakan dalam meningkatkan partisipasi pemilih perempuan pada Pilkada serentak di Kota Magelang adalah pendekatan formal, informal dan media massa. ${ }^{6}$

Perbedaan penelitian ini dengan penelitian terdahulu, yaitu peneliti memfokuskan untuk meneliti partisipasi dari pemilih perempuan, serta peneliti ingin melihat apakah faktorfaktor yang mempengaruhi partisipasi pemilih perempuan pada Pileg tahun 2019 di Kecamatan Koto Tangah Kota Padang dengan menggunakan teori partisipasi politik Ramlan Surbakti.

Dilihat dari Pileg tahun 2014 lalu di Kota Padang, tingkat partisipasi pemilih perempuan dari tahun 2014 ke tahun 2019 mengalami peningkatan. Begitu juga dengan tingkat partisipasi pemilih perempuan di Kecamatan Koto Tangah juga mengalami peningkatan. Yaitu sejumlah 40.079 ribu jiwa pemilih perempuan di Kecamatan Koto Tangah dari tahun 2014 ke 52.661 ribu jiwa pemilih perempuan di Kecamatan Koto Tangah pada tahun 2019.

Melihat dari meningkatnya partisipasi pemilih perempuan pada pileg tahun $2014 \mathrm{ke}$ tahun 2019 tentu menjadi fenomena yang cukup menarik untuk dikaji secara mendalam terkait faktor-faktor yang mempengaruhi partisipasi pemilih perempuan tersebut. Berdasarkan uraian di atas peneliti tertarik untuk meneliti apakah faktor-faktor yang

\footnotetext{
${ }^{5}$ Ana Maria Gadi Djou MA dan Liza Quintarti. 2018. Partisipasi Perempuan dalam Partai Politik dan Pemilu Serempak. Jurnal UNNES. Vol.4. No. 3. Hal 610.

${ }^{6}$ Eko Ari Wibowo, dkk. 2019. Strategi Sosialisasi Politik Dalam Peningkatan Partisipasi Pemilih Perempuan Pada Pilkada Serentak di Kota Magelang. Jurnal Ilmu Pemerintahan. Vol 05. No. 01. Hal 41-41.
} 
mempengaruhi partisipasi pemilih perempuan pada pemilu legislatif tahun 2019 di Kecamatan Koto Tangah, Kota Padang?

\section{Konsep Partisipasi Politik}

Partisipasi secara harfiah berarti keikutsertaan. Dalam konteks politik hal ini mengacu pada keikutsertaan warga dalam berbagai proses politik. Partisipasi politik dapat juga dipahami sebagai proses keterlibatan warga dalam segala tahapan kebijakan, mulai dari sejak pembuatan keputusan sampai dengan penilaian keputusan, termasuk juga peluang untuk ikut serta dalam pelaksanaan keputusan. ${ }^{7}$ lain $:^{8}$

Menurut Ramlan Surbakti, faktor-faktor yang mempengaruhi partisipasi politik antara

1. Status sosial dan ekonomi

Status sosial ialah kedudukan seseorang dalam masyarakat karena keturunan, pendidikan dan pekerjaan. Sedangkan status ekonomi ialah kedudukan seseorang dalam pelapisan masyarakat berdasarkan pemilikan kekayaan. Seseorang yang memiliki status sosial yang tinggi diperkirakan tidak hanya memiliki pengetahuan politik, tetapi juga mempunyai minat dan perhatian pada politik.

2. Situasi

Menurut Ramlan Surbakti, situasi politik juga dipengaruhi oleh keadaan yang mempengaruhi aktor secara langsung seperti, cuaca, keluarga, kehadiran orang lain, keadaan ruang, suasana kelompok, dan ancaman.

3. Afiliasi politik orang tua

Afiliasi berarti tergabung dalam suatu kelompok atau kumpulan. Afiliasi politik dapat dirumuskan sebagai keanggotaan atau kerjasama yang dilakukan individu atau kelompok yang terlibat ke dalam aliran-aliran politik tertentu. Afiliasi politik mendorong tumbuhnya kesadaran dan kedewasaan politik masyarakat untuk menggunakan hak pilihnya secara bebas dan bertanggung jawab dalam melakukan berbagai aktivitas politik, seperti ikut dalam partai politik, dalam pemerintahan, ikut dalam pengambilan dan pelaksanaan keputusan politik.

4. Kesadaran Politik

Kesadaran akan hak dan kewajiban sebagai warga negara yang menyangkut tentang pengetahuan seseorang tentang lingkungan masyarakat dan politik, dan menyangkut minat dan perhatian seseorang terhadap lingkungan masyarakat dan politik tempat dia hidup.

5. Kepercayaan terhadap Pemerintah.

Kepercayaan terhadap Pemerintah ialah penilaian seseorang terhadap Pemerintah apakah ia menilai Pemerintah dapat dipercaya dan dapat dipengaruhi atau tidak, baik dalam pembuatan kebijakan-kebijakan atau pelaksanaan pemerintah.

${ }^{7}$ Doni Hendrik. 2010. Variabel-Variabel Yang Mempengaruhi Rendahnya Partisipasi Politik Masyarakat Dalam Pilkada Walikota dan Wakil Walikota Padang Tahun 2008. Jurnal Demokrasi. Vol. IX. No. 2. Hal 140.

${ }^{8}$ Ibid. Hal 141-142 


\section{METODE PENELITIAN}

Penelitian ini menggunakan metode penelitian deskriptif melalui pendekatan kualitatif dengan menggunakan metode studi kasus. Yang dimaksud dengan penelitian kualitatif adalah penelitian yang bermaksud untuk memahami fenomena tentang apa yang dialami oleh subjek penelitian secara holistic, dan dengan cara deskripsi dalam bentuk kata-kata dan bahasa, pada suatu konteks khusus yang alamiah dengan memanfaatkan berbagai metode ilmiah. Secara sederhana, dapat dinyatakan bahwa penelitian kualitatif adalah meneliti informan sebagai subjek penelitian dalam lingkungan kesehariannya. ${ }^{9}$

Dengan metode penelitian kualitatif ini diharapkan kita dapat mengetahui apa faktorfaktor yang mempengaruhi partisipasi pemilih perempun pada pileg tahun 2019 di kecamatan Koto Tangah Kota Padang. Karena sebagaimana kita tahu bahwasannya dalam partisipasi politik sebagai pemilih harus melibatkan pemilih laki-laki maupun pemilih perempuan. Sehingga di sini kita dapat melihat apakah faktor-faktor yang mempengaruhi partisipasi pemilih, terutama disini peneliti lebih berfokus pada partisipasi dari pemilih perempuan.

Studi kasus yang digunakan dalam penelitian ini adalah studi kasus intrinsik. Yang mana pada penelitian ini digunakan studi kasus intrinsik karena peneliti tertarik mengangkat kasus ini secara lebih mendalam, mengingat data yang telah peneliti paparkan sebelumnya terkait meningkatnya partisipasi pemilih perempuan pada tahun 2014 ke 2019. Sehingga dalam penelitian ini peneliti ingin mengetahui lebih lanjut terkait faktor-faktor yang mempengaruhi partisipasi pemilih perempuan pada pileg tahun 2019 di Kecamatan Koto Tangah kota Padang.

\section{HASIL DAN PEMBAHASAN}

Partisipasi merupakan suatu mekanisme yang penting dalam suatu negara, dan pemilihan umum merupakan salah satu bentuk dari partisipasi politik. Setiap warga negara berhak untuk ikut serta dalam pemilihan umum tanpa terkecuali, begitu juga dengan perempuan. Partisipasi politik merupakan kegiatan yang dapat dipengaruhi oleh berbagai faktor. Faktor-faktor tersebut seperti kesadaran politik, kepercayaan terhadap pemerintah, status sosial dan status ekonomi, afiliasi politik orang tua dan situasi.

Berdasarkan rumusan masalah penelitian dilatar belakang penelitian, bahwasannya ada peningkatan partisipasi pemilih perempuan di Kecamatan Koto Tangah pada Pemilihan Umum Legislatif tahun 2019.Kontestasi pemilu legislatif pada tahun 2019 menjadi menarik ketika pengalaman pemilu legislatif dalam beberapa dekade terakhir menunjukkan semakin meningkatnya partisipasi pemilih perempuan. Dimana pemilih perempuan sangat antusias dalam berpartisipasi dan mendukung pelaksanaan pemilu legislatif tahun 2019.

a. Kesadaran Politik

${ }^{9}$ Muhammad Idrus. 2009. Metode Penelitian Ilmu Sosial. Yogyakarta: Erlangga. Hal 23. 
Faktor kesadaran politik sangat mempengaruhi pemilih perempuan dalam berpartisipasi politik memberikan hak suaranya pada pemilu legislatif tahun 2019 di Kecamatan Koto Tangah. Menurut Ramlan Surbakti, jika kesadaran politik yang dimiliki oleh seseorang itu tinggi, maka tingkat partisipasinya akan cenderung aktif. Pernyataan tersebut benar adanya terdapat dalam realita pemilih perempuan di Kecamatan Koto Tangah dalam berpartisipasi politik pada pemilu legislatif tahun 2019. Adanya keinginan dari pemilih perempuan untuk turut serta dalam berpartisipasi politik berdasarkan kesadaran politiknya.

Di kecamatan Koto Tangah ini tingkat kesadaran pemilih perempuan itu sangat tinggi.Pemilih perempuan merupakan bagian besar dari pemilih laki-laki, karena jumlah perempuan yang banyak. Oleh karena itu pemilih perempuan harus memilih secara bijaksana. Sebab pilihannya nanti dapat menentukan nasib bangsa ini.

Sebagai warga negara Indonesia, kita memang diberikan hak untuk ikut berpartisipasi. Sesuai dengan Undang-Undang Pemilu tahun 2017 tentang kesempatan kepada semua warga negara yang telah memenuhi persyaratan untuk turut serta berpartisipasi politik. Oleh karena itu, setiap warga negara Indonesia baik laki-laki maupun perempuan berhak memberikan hak suaranya. Kesadaran politik warga negara dalam hal ikut serta dalam proses pemilihan legislatif merupakan faktor yang sangat mendasar. Artinya masyarakat harus mengerti pentingnya ikut berpartisipasi, dan masyarakat diharuskan memahami akan hak dan kewajiban mereka sebagai warga negara yang berkaitan dengan lingkungan masyarakat dan kegiatan politik.

Partisipasi pemilih perempuan dalam politik perlu terus ditingkatkan, mengingat secara kuantitatif jumlah perempuan lebih banyak dibanding jumlah laki-laki. Partisipasi politik merupakan urgensi karena pertumbuhan demokrasi bergantung pada sejauh mana keikutsertaan para anggota masyarakat khususnya perempuan yang secara aktif terlibat dalam menentukan tujuan politik. Seperti halnya di Kecamatan Koto tangah, pemilih perempuannya memiliki kesadaran politik yang tinggi dalam bentuk kesadaran untuk menggunakan hak pilihnya dengan datang ke TPS memberikan suaranya pada pemilu legislatif tahun 2019, dan kesadaran politik tentang perlunya pemerintah yang legitimate (sah) dan yang lebih baik lagi. Kesadaran politik seperti ini tentu perlu untuk terus ditingkatkan lagi.

b. Kepercayaan kepada pemerintah

Faktor kepercayan kepada pemerintah menjadi salah satu faktor pemilih perempuan dalam berpartisipasi politik pada pemilu legislatif tahun 2019. Seperti halnya pada penelitian yang dilakukan oleh Mery Anggraini, Asrinaldi dan Aidinil Zetra yang berjudul Pengaruh Kesadaran Dan Kepercayaan Politik Terhadap Partisipasi Politik Masyarakat Dharmasraya Pada PILKADA 2015. Disana dijelaskan bahwa kepercayaan terhadap pemerintah merupakan salah satu faktor yang mempengaruhi partisipasi politik seseorang. Jika masyarakat merasa kecewa terhadap pemerintah, maka salah satu cara masyarakat menunjukkan rasa kekecewaan tersebut adalah dengan memilih calon pemimpin baru pada PILKADA yang sekiranya diharapkan dapat membawa perubahan menuju harapan baru. ${ }^{10}$

\footnotetext{
${ }^{10}$ Mery Anggarini, Asrinaldi, dan Aidinil Zetra. 2018. Pengaruh Kesadaran Dan Kepercayaan Politik Terhadap Partisipasi Politik Masyarakat Dharmasraya Pada PILKADA 2015. Jurnal Madania. Vol 8 : 1. Hal 112.
} 
Sama halnya dengan pemilih perempuan di Kecamatan Koto Tangah, kepercayaan kepada pemerintah merupakan salah satu faktor yang mendorong pemilih perempuan untuk ikut memilih. Namun, pada pemilih perempuan yang tidak percaya kepada pemerintah malah justru tetap ikut memilih. Sebab, ia berharap dengan ikut memilih pada pemilu legislatif dapat membawa perubahan dalam pemerintahan. Dengan harapan terpilihnya caleg yang dirasa pantas dan mampu duduk di parlemen yang nantinya dapat membuat kebijakankebijakan yang lebih mengutamakan masyarakat.

Menurut Ramlan Surbakti, jika kepercayaan terhadap pemerintah tinggi, maka partisipasi seseorang akan cenderung aktif, begitu pun sebaliknya. Namun, realita yang terjadi pada pemilih perempuan di Kecamatan Koto Tangah pada pemilu legislatif tahun 2019, kepercayaan terhadap pemerintah yang rendah malah membuat ia ingin berpartisipasi politik memberikan suaranya. Hal ini tentu menjadi menarik dan sekaligus menjadi penemuan terbaru dalam penelitian ini.

c. Status sosial dan status ekonomi

Faktor status sosial dan ekonomi menjadi salah satu faktor pemilih perempuan di Kecamatan Koto Tangah dalam berpartisipasi politik pada pemilu legislatif tahun 2019. Namun, pada beberapa pemilih perempuan lainnya status sosial dan status ekonomi sama sekali tidak mempengaruhi mereka dalam berpartisipasi politik.

Dapat dilihat juga bahwasannya, faktor status sosial dan status ekonomi merupakan suatu hal yang relatif bagi pemilih perempuan di Kecamatan Koto Tangah untuk mendorongnya ikut berpartisipasi politik pada pemilu legislatif tahun 2019. Hal ini terlihat dari beberapa wawancara dengan para informan. Yang mana menurut beberapa informan, status sosial bisa menjadi salah satu faktor dalam ia ikut berpartisipasi dan bisa juga tidak menjadi faktor dalam ia ikut berpartisipasi, begitu juga dengan faktor status ekonomi. Para informan menyatakan bahwasannya keikutsertaan mereka dalam pemilu legislatif tahun 2019 sesuai dengan keinginan mereka dikarenakan kesadaran politik yang mereka miliki sebagai warga negara yang memiliki hak untuk memilih. Sehingga, dengan harapan dapat mencapai suatu perubahan yang lebih baik. Dan juga beberapa informan berpendapat bahwa status ekonomi menjadi acuan mereka dalam berpartisipasi dengan harapan dapat meningkatkan perekonomian mereka ke arah yang lebih baik.

\section{d. Situasi politik}

Faktor situasi politik dipengaruhi oleh keadaan yang mempengaruhi aktor secara langsung seperti cuaca, keluarga, kehadiran orang lain, keadaan ruang, suasana kelompok dan ancaman. pemilih perempuan di Kecamatan Koto Tangah dalam berpartisipasi politik pada pemilu legislatif tahun 2019 tidak dipengaruhi oleh keadaan di Tps, dan lingkungan sekitar. Namun, pendapat orang tua dan suami mempengaruhi pemilih perempuan dalam berpartisipasi politk. 


\section{Bentuk-Bentuk Partisipasi Politik Pemilih Perempuan Di Kecamatan Koto Tangah Pada Pemilu Legislatif Tahun 2019}

Bentuk partisipasi politik seseorang tampak dalam aktivitas-aktivitas politiknya, begitu pula dengan pemilih perempuan yang ada di Kecamatan Koto Tangah Kota Padang. Di Kecamatan Koto Tangah Kota Padang partisipasi politik yang mereka lakukan berupa :

a. Pemberian Suara

Pemilih perempuan di Kecamatan Koto Tangah memiliki cara pandang yang berbedabeda dalam mengekspresikan partisipasi politiknya. Dan salah satu bentuk dari partisipasi politik pemilih perempuan di Kecamatan Koto Tangah dalam pemilu legislatif tahun 2019 adalah dengan pemberian suara. Hal ini dapat dilihat dari antusiasnya jumlah pemilih perempuan di Kecamatan Koto Tangah yang sangat tinggi.Pemilih perempuan secara umum sangat antusias dalam memberikan hak pilihnya pada pemilu legislatif tahun 2019 ini.

Hal ini dapat dilihat dari berita acara pemungutan suara dan penghitungan suara pemilih yang terdaftar dalam daftar pemilih tetap 132.448 pemilih, diantaranya datang ke TPS untuk memberikan suaranya sekitar 97.488 pemilih pada pemilu legislatif tahun 2019 ini. Pemilih perempuan di Kecamatan Koto Tangah sendiri yang terdaftar dalam daftar pemilih tetap berjumlah 67.051 pemilih dan berdasarkan daftar hadir di seluruh TPS yang terdapat di Kecamatan Koto Tangah tercatat 52.661 diantaranya memberikan suaranya. Tingginya angka pemilih perempuan yang yang memberikan suaranya dalam pemilu legislatif tahun 2019, menunjukkan bahwa pemilih perempuan tidak kalah antusias seperti halnya pemilih laki-laki di Kecamatan Koto Tangah.

b. Menjadi Panitia Penyelenggara Pemilu Legislatif Tahun 2019

Salah satu bentuk partisipasi politik yang dilakukan oleh pemilih perempuan di Kecamatan Koto Tangah pada pemilu legislatif tahun 2019 adalah dengan menjadi panitia penyelenggara pemilu yaitu anggota KPPS. Partisipasi pemilih perempuan dengan menjadi anggota KPPS didasari oleh beragam alasan, ada yang ingin menjadi anggota KPPS karena sudah terpilih oleh masyarakat dan merasa diberikan amanah dan amanah tersebut harus dijalankan dengan sebaik mungkin, ada yang ingin mendapatkan pengalaman jadi anggota KPPS, serta ada juga yang ingin menyukseskan pemilu dan menjamin pemilu akan berlangsung dengan langsung, umum, bebas, rahasia, jujur dan adil.

c. Berbicara Masalah Politik

Pada musim pemilihan umum legislatif, orang suka membicarakan tentang masalahmasalah dan peristiwa-peristiwa politik yang terkait. Meskipun bersifat informal, tidak jarang diskusi-diskusi semacam itu berlangsung menarik. Karena disana orang dapat mengeluarkan pendapatnya dengan bebas serta sikap politiknya. Hal ini dimungkinkan karena adanya 
hubungan kekeluargaan diantara peserta diskusi tersebut dan juga hubungan persahabatan serta lingkungan sekitar.

Pemilu legislatif tahun 2019 mempunyai hal yang cukup menarik di hati pemilih perempuan di Kecamatan Koto Tangah. Hal ini dibuktikan dari hasil wawancara dengan beberapa informan yang menyatakan bahwa mereka sering membicarakan bahkan mendiskusikan tentang masalah pemilu dengan keluarganya di rumah dan teman-temannya di sela-sela kegiatan mereka sehari-hari, tak jarang juga bagi pemilih perempuan khususnya ibuibu yang mengikuti arisan di lingkungannya, ia membahas mengenai politik di tempat arisan tersebut. Karena membicarakan masalah politik merupakan salah satu bentuk partisipasi politik yang mudah untuk dilakukan oleh semua orang. Berbicara mengenai masalah politik tentu juga merupakan hal yang seru, karena seperti halnya ketika membicarakan masalah pemilu legislatif dengan teman nantinya akan ada perdebatan-perdebatan kecil tentang siapa calon legislatif yang akan dipilih dan partai pilihan masing-masing yang membuat suasana berbicara semakin asyik ketika kita saling membicarakan hal tersebut.

\section{KESIMPULAN}

Penelitian ini berusaha untuk meneliti tentang faktor yang mempengaruhi partisipasi pemilih perempuan pada pemilu legislatif tahun 2019 di Kecamatan Koto Tangah Kota Padang. Partisipasi pemilih perempuan dijadikan sebagai wadah bagi pemilih perempuan untuk turut serta dalam membawa perubahan bagi negara untuk menjadi lebih baik. Setelah peneliti menemukan temuan-temuan dari analisis peneliti, maka peneliti memberikan kesimpulan bahwa faktor-faktor yang mempengaruhi partisipasi pemilih perempuan pada pemilu legislatif tahun 2019 di Kecamatan Koto Tangah, Kota Padang adalah adanya kesadaran politik yang tinggi dari pemilih perempuan bahwa sebagai warga negara yang baik itu harus menggunakan hak pilihnya untuk memilih wakil rakyat yang duduk di pemerintahan. Adanya keinginan dan harapan dari pemilih perempuan, dengan ikut berpartisipasi politik itu nantinya dapat membawa perubahan yang lebih baik dalam pemerintahan.

Selanjutnya faktor kepercayaan kepada pemerintah, menariknya dari hal ini sekaligus yang menjadi penemuan terbaru. Pada pemilih perempuan yang tidak memiliki kepercayaan kepada pemerintah malah justru membuat ia ikut memilih. Sebab, ia berharap dengan ikut memilih pada pemilu legislatif dapat membawa perubahan dalam pemerintahan. Dengan harapan terpilihnya caleg yang dirasa pantas dan mampu duduk di parlemen yang nantinya dapat membuat kebijakan-kebijakan yang lebih mengutamakan masyarakat.

Selanjutnya pengaruh faktor status sosial dan status ekonomi yang mempengaruhi pemilih perempuaan di Kecamatan Koto tangah Kota Padang dalam memberikan suara untuk memilih. Faktor status sosial ini dikarenakan pekerjaan yang dimiliki oleh pemilih perempuan, dan faktor status ekonomi yang dimiliki oleh pemilih perempuan dikarenakan pemilih perempuan menginginkan adanya perubahan perkembangan ekonomi menjadi lebih baik lagi. 
Selanjutnya faktor dukungan orang tua yang mempengaruhi pemilih perempuan di Kecamatan Koto tangah Kota Padang dalam memberikan suara untuk memilih. Pemilih perempuan ikut memilih pada pemilu legislatif karena disarankan oleh orang tuanya. Dan sebagai seorang anak sudah seharusnya untuk mematuhi apa yang dikatakan orang tua. Terlebih hal tersebut juga merupakan hal yang positif. Selanjutnya faktor pendapat suami ikut mempengaruhi pemilih perempuan di Kecamatan Koto tangah Kota Padang dalam memberikan suara untuk memilih.

Selanjutnya dalam penelitian ini, juga ditemukan bahwa bentuk-bentuk partisipasi politik yang dilakukan oleh pemilih perempuan di Kecamatan Koto Tangah adalah dengan memberikan suara, menjadi panitia penyelenggara pemilu, serta membicarakan masalah politik.

\section{DAFTAR PUSTAKA}

Anggarini, Mery, Asrinaldi, dan Aidinil Zetra. 2018. Pengaruh Kesadaran Dan Kepercayaan Politik Terhadap Partisipasi Politik Masyarakat Dharmasraya Pada PILKADA 2015. Jurnal Madania. Vol 8.

Gadi Djou, Ana Maria dan Liza Quintatarti. 2018. Partisipasi Perempuan dalam Partai Politik dan Pemilu Serempak. Jurnal UNNES.

Hendrik, Doni. 2010. Variabel-Variabel Yang Mempengaruhi Rendahnya Partisipasi Politik Masyarakat Dalam Pilkada Walikota dan Wakil Walikota Padang Tahun 2008. Jurnal Demokrasi. Vol. IX. No. 2.

Idrus, Muhammad. 2009. Metode Penelitian Ilmu Sosial. Yogyakarta: Erlangga.

Miriam Budiardjo. 2008. Dasar-Dasar Ilmu Politik. Jakarta: Gramedia Pustaka Utama.

Safitri, Rani S.Sos \& Dr. Oksep Adhayanto., MH. 2017. Partisipasi Politik Perempuan Dalam Menyukseskan Pemilu Legislatif Tahun 2014 Di Kelurahan Sungai Lekop Kabupaten Bintan. Jurnal Ilmu Pemerintahan. Vol. 2. No. 1.

Wibowo, Ari Eko dkk. 2019. Strategi Sosialisasi Politik Dalam Peningkatan Partisipasi Pemilih Perempuan Pada Pilkada Serentak di Kota Magelang. Jurnal Ilmu Pemerintahan. Vol 05.

Widodo, Wahyu. 2018. Pelaksanaan Pemilu Serentak Tahun 2019 Ditinjau Dari Perspektif Politik Dan Hukum. Jurnal Meta-Yuridis. Vol 1. No 1. 